\title{
Permissive Attitude toward LGBT in Jakarta: Study of Differences in the Level of Permissiveness among individuals born in 1950-1970's and 1980-2000's
}

\author{
Endang Setiowati, ${ }^{1, *}$ \\ ${ }^{1}$ Faculty Member, Communication Studies, Vocational Program, Universitas Indonesia
}

\begin{abstract}
Lesbian, Gay, Bisexual and Transgender (LGBT) movement is strongly resisted in Indonesia. This is not only that Indonesian people are still religious, but also the traditional norms and values are still very strong in daily life. Based on the Pew Research Centre in 2014, the homosexuality level of acceptance in Indonesia is only about $3 \%$, while the rejection is $93 \%$. LGBT has been started since the 1960 s, but it became strength since the private television in early 1990s promoted the effeminate characters to be the top celebrities paid hundreds of millions of rupiah. People who born in the 1950s to 1970s that consume only one TV station will have different respond to LGBT with people who born in the 1980s to 2000s with some TV stations. Purpose: to look for the differences in the level of permissiveness toward homosexuality between those two groups of people. Method: using a mix method of qualitative and quantitative. Qualitative methods interviewed 6 informants. The quantitative will be a survey of 100 respondents. Result: The level of permissiveness on LGBT of the younger group is higher than the older group. According to acceptance factor both group mostly reject LGBT. But according to properness, the older group tend to say disturbing and disgusting, while for the younger group assume not disturbing.
\end{abstract}

\section{Introduction}

At the end of January 2016 appeared a poster that was distributed virally through social media. The poster mentioned if a student from the University of Indonesia (UI) offer counselling services to lesbian, gay, bisexual, and transgender (LGBT). The poster also emphasized that they are not alone and the institutions called themselves as the Support Group and Resource Centre on Sexuality Studies (SGRC) will help them cope with difficult times as a result of the identity crisis. In the posters also contained the photos and names of four students and alumni who pose as LGBT persons. Suddenly the poster became a trending topic on various social media as well as in the mass media.

Indeed the LGBT issue becomes widespread in the media and in the community chatter. The pros and cons opinion also appear. This is because LGBT is still a taboo. Results of research on Global Attitudes Project conducted by the Pew Research Centre in the year 2013 which was updated in 2014 stated that the level of acceptance of LGBT socially in Indonesia only reaches 3\% only, while rejecting as much as $93 \%$. Level of public acceptance is not just because of religious interpretation but also norms and values of Indonesian people who are not comfortable against LGBT presence [1].

* Corresponding author: setiowati@gmail.com 
The LGBT movement became strength after it promoted by some private TV stations that established in the early of 1990s. Private TV stations compete with each other to show the effeminate figures in any program to attract an audience. At first the effeminate figures is only used as the butt or derision, but in line with the increase in the rating on each program featuring the effeminate figures, it became a new commodity for private TV stations. After the 90 s came the new pansy celebrities such as the late Olga, the late Avi, Ivan Gunawan, or a feminine figure of a man like Indra Bekti, Irvan Hakim, Ruben Onsu and so forth.

Characterizations of gay and lesbian began to frequently show in soap operas or movies. It seems that homosexual began to be accepted and considered normal by society. For people born in the 1950 s to the 1970 s, of course characterizations of gay, lesbian and transvestite could be something disturbing. because although many effeminate figures like Sukardjo AC/DC, Tessy Srimulat, even the late Benjamin S and Bing Slamet, the two famous Indonesian comedian ever played a transvestite or effeminate figures in their movies.. But people know that they are actually a man in real life. Unlike the effeminate figures appearing on private TV era, where in real life they also show their love in the same sex. They also dress up as women in their real life. This could lead to them being born in the 1980 s to the 2000 s, which was the main target of the private TV, will become accustomed to seeing the effeminate figure in real life.

This research will focus on how those two groups of people in seeing the LGBT. Whether or not they have different opinion and attitude toward LGBT.

\section{Literature Review}

LGBT movement in Indonesia has existed since at least the 1960's which then began to develop in the 1980s along with the popularity of Fantastic Dolls dance group consisting of the transvestites. This movement began to explode in the new millennium until now. The first LGBT organization is the Association of transvestites Djakarta (HIWAD), that was protested by the Indonesian Ulema Council (MUI). In the 1980s established various organization focus on LGBT empowerment such as Lambda Indonesia for gay people, PERLESIN for lesbian and the most well-known is GAYa Nusantara that embodies the gay, lesbian, and transgender. [2] The dramatic changes occur in the political system and the government in 1998 in which freedom of opinion started to become a staple. Indonesian Women's Congress in December 1998 formally include representatives of lesbians, bisexual women and transgender men and include them in the sector $\mathrm{XV}$ in the organization of Women's Coalition for Justice and Democracy (KPI)

The rise of activities and campaigns in favour of the movement of Lesbian, Gay, Bisexual, and Transgender (LGBT), either directly or indirectly, have negative effects for society and especially the child's age. Moreover, LGBT campaigns conducted through information channels and social media users are target school age children and adolescents.

Apparently, had many children and adolescents are victims of age. Data compiled by the Ministry of Education and Culture in 2016, it seems LGBT children and adolescents in the world is quite serious. There are 3000 students in the city of Batam known as a predominantly gay. [3]

AusAID survey, as many as 700 or $22 \%$ of children aged 16-20 years in Tanjungpinang and Bintan behaves likes the same sex. Increased homosexual HIV sufferers of $6 \%$ (2008) to 8\% (2010) and continues to be $12 \%$ (2014). Furthermore, there is a SD Gay community, Gay junior high school Gay number of followers on twitter with thousands. At the same time, there are 119 organizations that are concerned about LGBT issues in Indonesia and the numbers continue to rise. [3]

The research conducted in 3 cities, Shanghai, Hanoi, and Taipei on adolecents and young adults perception of Homosexuality showed that adolescents and young adults of higher economic status and educational level, whether they are students or not, and/or if from an urban area, are likely to have a more positive perception of homosexuality. The other findings showed that increased media viewing is correlated with a more favorable perception of homosexuality, and this relationship is most pronounced for those with the least amount of social contact with lesbians and gay men. Media 
may be able to influence the beliefs of adolescents and young adults, particularly, for those who have little direct social contact [4].

\section{Methods}

This study uses qualitative and quantitative approaches. [5] The qualitative research interviews 6 informants consisting of a woman born in 1955 (WM), a man born in 1961(DA), a man born in 1977 (AZ), a woman born in 1983(DK), a woman born in 1992 (KL) and a man born in 2001(AA). Questions about how their opinion on LGBT and whether they agrees that persons with LGBT that remains themselves or had to go and get back into a man or woman as nature.

Quantitative research is the development results of interviews with six informants in qualitative research. The research was conducted online, and the link of the questionnaires distributed via Twitter, Facebook, some chat groups in Blackberry, WhatsApp, and Telegram, to the people who were born in 1950 to 2001 or from 15 years old to 66 years old. Restrictions birth year to 2001 is because they were born in the year, is already 15 years old and went to high school, considered opinions given quite trustworthy.

Using close and open ended questionnaires, as many as 11 questions related to 3 major topics such as LGBT as abnormal behaviour, the role or characterizations of a LGBT in the TV program and also about the existence of the LGBT their environment. Time distribution of the questionnaire was for three days and got 187 responses.

From the 187 responses obtained, consisting of 63 men (34\%) and 124 women $(66 \%)$. Age is composed of 77 people (41\%) aged 37 to 66 years and $110(59 \%)$ aged 15 to 36 years. Their domicile is in South Jakarta as many as 51 people (27.3\%), East Jakarta 22 people (11.8\%), West Jakarta $18(9.6 \%)$, Central Jakarta 3 (1.6\%), North Jakarta 2 ( $1.1 \%)$ and those living around Jakarta (Depok, Bogor, Bekasi, and Tangerang) as many as 91 people (48.7\%).

Religious affiliation of respondents is 131 people (70.1\%) are Muslims, 29 people $(15.5 \%)$ are Christians, 23 people (12.3\%) are Catholic, 1 person (0.5\%) are Hindu and 3 people $(1,6 \%)$ replace it with words that are not related to religion, and one person call himself, as a humanist.

\section{Results}

\subsection{Result of Qualitative Research}

They were born in the 1950 s to the 1970 s and 1980 s to the 2000s birth assume that LGBT is an inappropriate behaviour as incompatible with religion and norms of Indonesian life. But their opinion is different when asked whether LGBT is a disruption to their lives. The older groups regarded as intrusive and should be eliminated from television shows and movies. Such as what WM said,

“.... presenter seperti Olga..maaf bukan mau ngungkit yang sudah almarhum ya.. atau Ivan Gunawan itu kenapa sih harus diekspos? Kan bisa cari orang lain. Kayaknya tuh kalo bencong pasti laku.."

The older group also assume that homosexual behaviour is contagious behaviour that should be prohibited from developing in Indonesia. Such as what DA said,

"... homoseksual itu menular lho.. di kantor saya ada satu boss lain bagian sama saya yang nyata banget kalo dia itu hombreng, eh.. tahu-tahu anak buah dia berubah semua jadi gemulai... saya tahu banget ada seorang yang tadinya normal cowok banget sekarang kelihatan jadi berubah salon banget penampilannya, terus juga baju-bajunya kelihatan banget deh udah jadi hombreng sekarang..."

However, about LGBT can be contagious is also stated by one informant who was born in 1983 know that DK as she said the following,

"...menurut saya seperti penyakit bisa menular karena temen saya pernah menjadi korbannya.. kalo keganggu atau ngga, sedikit terganggu karena dalam agama manapun ngga ada yang mendukung lgbt ini.. kalo buat berobat atau ke psikiater 
menurut saya kalo dalam dirinya merasa benar mau diobatin gimanapun bakalan susah..."

While the younger group was not bothered, because there are many LGBT in their peer groups. So if there is a rule should prohibit LGBT scene containing on television does not also have an impact on their environment which is already a LGBT. According to them, people who have LGBT indeed consciously choose their life. As far as the LGBT do not interfere with their lives and do not invite them to join their LGBT, they would not pay attention to their existence. Such as KL said,

“...gak masalah... banyak koq mahasiswa yang hombreng.. kalo lesbi belom pernah kenal... pokoknya asal mereka gak gangguin saya..gak ngusik hidup saya ya biar aja mereka toh punya komunitasnya sendiri kan, jadi meski di TV ada larangan penampilan LGBT kayaknya gak ngaruh deh... yang hombreng tetep aja hombreng.."

As well as the AA 15-year-old boy said,

“...selama mereka tidak menyinggung sesuatu yang bersangkutan dengan kesusilaan dan agama saya rasa sih fine2 aja, toh itu hanya hiburan..."

\subsection{Result of Quantitative Research}

The quantitative analysis is using SPSS Version 21. Regarding the responses to the question whether LGBT is an abnormal behaviour, the majority of respondents, 148 (79.1\%) responded that LGBT as abnormal behaviour. When viewed from the age of 62 turned out to vote $(80.5 \%)$ of respondents aged 37 to 66 years stated LGBT abnormal behaviours, while from age 15 to 36 years as many as 86 people (78.2\%). If the views of gender turned out $85.7 \%$ of men (54 people) stated that LGBT abnormal behaviour, while women only $75.8 \%$ (94 people).

In terms of religion, the majority stated LGBT is an abnormal behaviour. The one and only Hindu respondent also stated that LGBT is an abnormal behaviour. On the contrary, they who are not state religion, the majority $66.7 \%$ (2 persons) states that LGBT is normal behaviour. From the majority of the states LGBT is an abnormal behaviour, those who are Catholic turns out the largest percentages that is $87 \%$ (20 people). While the Muslims respondents who are the majority of respondents only $78.6 \%$ (103 people).

Table 1. LGBT as an Abnormal Behavior by Age and Religion

\begin{tabular}{|c|c|c|c|c|c|c|c|c|}
\hline \multirow{2}{*}{ AGE } & & & \multicolumn{5}{|c|}{ RELIGION } & \multirow{2}{*}{ TOTAL } \\
\hline & & & 1 & 2 & 3 & 4 & 5 & \\
\hline \multirow{6}{*}{$\begin{array}{c}37-66 \\
\text { у.о }\end{array}$} & \multirow{3}{*}{$\mathrm{Y}$} & Count & 35 & 15 & 11 & & 1 & 62 \\
\hline & & $\%$ within topic & $56.5 \%$ & $24.2 \%$ & $17.7 \%$ & & $1.6 \%$ & $100.0 \%$ \\
\hline & & \% within religion & $83.3 \%$ & $83.3 \%$ & $73.3 \%$ & & $50.0 \%$ & $80.5 \%$ \\
\hline & \multirow{3}{*}{$\mathrm{N}$} & Count & 7 & 3 & 4 & & 1 & 15 \\
\hline & & $\%$ within topic & $46.7 \%$ & $20.0 \%$ & $26.7 \%$ & & $6.7 \%$ & $100.0 \%$ \\
\hline & & $\%$ within religion & $16.7 \%$ & $16.7 \%$ & $26.7 \%$ & & $50.0 \%$ & $19.5 \%$ \\
\hline \multirow{6}{*}{$\begin{array}{c}15-35 \\
\text { у.о }\end{array}$} & \multirow{3}{*}{$\mathrm{Y}$} & Count & 68 & 5 & 12 & 1 & 0 & 86 \\
\hline & & $\%$ within topic & $79.1 \%$ & $5.8 \%$ & $14.0 \%$ & $1.2 \%$ & $0.0 \%$ & $100.0 \%$ \\
\hline & & $\%$ within religion & $76.4 \%$ & $100.0 \%$ & $85.7 \%$ & $100.0 \%$ & $0.0 \%$ & $78.2 \%$ \\
\hline & \multirow{3}{*}{$\mathrm{N}$} & Count & 21 & 0 & 2 & 0 & 1 & 24 \\
\hline & & \% within topic & $87.5 \%$ & $0.0 \%$ & $8.3 \%$ & $0.0 \%$ & $4.2 \%$ & $100.0 \%$ \\
\hline & & $\%$ within religion & $23.6 \%$ & $0.0 \%$ & $14.3 \%$ & $0.0 \%$ & $100.0 \%$ & $21.8 \%$ \\
\hline \multirow{4}{*}{$\begin{array}{c}\text { TOTA } \\
\text { L }\end{array}$} & \multirow{3}{*}{$\mathrm{Y}$} & Count & 103 & 20 & 23 & 1 & 1 & 148 \\
\hline & & $\%$ within topic & $69.6 \%$ & $13.5 \%$ & $15.5 \%$ & $0.7 \%$ & $0.7 \%$ & $100.0 \%$ \\
\hline & & $\%$ within religion & $78.6 \%$ & $87.0 \%$ & $79.3 \%$ & $100.0 \%$ & $33.3 \%$ & $79.1 \%$ \\
\hline & $\mathrm{N}$ & Count & 28 & 3 & 6 & 0 & 2 & 39 \\
\hline
\end{tabular}




\begin{tabular}{|c|c|r|r|r|r|r|r|}
\hline \multirow{2}{*}{ AGE } & & \multicolumn{7}{|c|}{ RELIGION } & \multirow{2}{*}{ TOTAL } \\
\cline { 2 - 8 } & & 1 & 2 & 3 & 4 & 5 & \\
\cline { 2 - 8 } & $\%$ within topic & $71.8 \%$ & $7.7 \%$ & $15.4 \%$ & $0.0 \%$ & $5.1 \%$ & $100.0 \%$ \\
\cline { 2 - 8 } & $\%$ within religion & $21.4 \%$ & $13.0 \%$ & $20.7 \%$ & $0.0 \%$ & $66.7 \%$ & $20.9 \%$ \\
\hline \multirow{3}{*}{$\begin{array}{c}\text { GRAND } \\
\text { TOTAL }\end{array}$} & Count & 131 & 23 & 29 & 1 & 3 & 187 \\
\cline { 2 - 8 } & $\%$ within topic & $70.1 \%$ & $12.3 \%$ & $15.5 \%$ & $0.5 \%$ & $1.6 \%$ & $100.0 \%$ \\
\cline { 2 - 8 } & $\%$ within religion & $100.0 \%$ & $100.0 \%$ & $100.0 \%$ & $100.0 \%$ & $100.0 \%$ & $100.0 \%$ \\
\hline
\end{tabular}

Note: 1. Muslim, 2.Catholic, 3. Christian, 4. Hindu, 5. Others

The reason why they consider LGBT is a most abnormal behaviour mostly is that LGBT violating the predetermined nature of Allah (50.8\%), violates the religious and social norms $(27.3 \%)$, and considers LGBT as a disease (7\%). While people who consider LGBT is not an abnormal behaviour mostly gave reason that people has the right to choose their own will $(9.6 \%)$, because LGBT is a destiny (2.7\%) and the impact of social environment $(1.6 \%)$. The interesting finding is even though there are some of them who say that LGBT violates the nature of God $(28.2 \%)$ and the abuse of religion (20.5\%) but they stated that LGBT is not an abnormal behaviour.

Regarding the response to the role or characterizations of a LGBT in the TV program, majority $75.4 \%$ (141 people) said that they often see the LGBT roles or characterizations exposed on TV programs. While when asked about whether they were bothered by the appearance of LGBT characters in TV program majority 68.4\% (128people) said they are bothered by the LGBT appearance on TV. But strangely when compared of those who responded had rarely or never seen LGBT appearances on TV, with whether they interfere with the LGBT appearances on TV, there were $65.2 \%$ (30 people) who stated annoyed with the LGBT characters exposed on TV. Whereas previously they claimed rarely or never seen LGBT characters on TV. Judging from age who answered annoyed with LGBT appearances on TV, as much as $68.8 \%$ (53persons) of aged 37 to 66 years, while respondents aged 15 to 36 years have much more percentages, as much as $68.2 \%$ (75 people) was disturbed by the appearance of LGBT on TV.

Regarding the response of whether LGBT appearances on TV should be banned, $73.3 \%$ (137 people) said that LGBT appearance on TV should be banned. When viewed from age, there were $72.7 \%$ (56 persons) aged 37 to 66 years stated LGBT should be banned on TV, while for those aged 15-36 years are also in line with the other age groups, a majority of $73.6 \%$ (81 people) considers LGBT appearances on TV should be banned.

Regarding the response of what to do if there is LGBT persons in their neighbourhood, mostly $(67.9 \%)$ stated that they will remain friend to the person, as long as they do not ask or persuade them to be LGBT. It is only $8 \%$ stated that they will not continue being friends with them. Relating to the age, $60 \%$ of people who will discontinue the relationship with the LGBT are from the age of 37 to 66 years. Respondents who stated that they will remain friend to the person, as long as they do not ask or persuade them to be LGBT are mostly from the age 15 to 36 years $(73.6 \%)$ while only $59.7 \%$ respondent of the age 37 to 66 years stated the same. Another interesting finding is respondent from the age of 37 to 66 years are more compromised to the LGBT as they stated that they will remain friend however their behaviour. It is $28.6 \%$ of those ages. While in the ages, is only $20,9 \%$ who stated that they will remain friend however their behaviour.

Regarding the question of what should be done if there is a person who induce or encourage others to be LGBT, mostly (72.7\%) stated that the LGBT person should be reprimanded and advised. $13.9 \%$ stated that as long as the person who was induced is accepted the invitation, so that they will do nothing. 9.6\% stated that the LGBT person should be severely punished. The rest of $3.2 \%$ of the respondent chose to answer in other reason, it was if the invited are children, then the LGBT should be punished, but if they are an adult, it is up to the invited. Relate to the age group, the age of 15 to 36 is more strictly because $11.9 \%$ from this group stated that they should be severely punishment, on the other hand only $6.5 \%$ of the age of 37 to 66 years stated the same.

Regarding the question what the LGBT persons should do for their life, there are three categories of answers, which almost have equal numbers of each. The highest number $(35.3 \%$ or 66 persons) is the answer that nothing to be done for them as long as he does not invite or influence 
others to be LGBT. Then $34.2 \%$ or 64 persons responded that they should find psychiatrist to be back normal. While the rest (30.5\% or 57 persons) tend to say that LGBT people should repent and strive to live a normal life. Relate to the age group most of the 37-66 years old tend to say that the LGBT persons should find medication to be back normal (39\%), while the 15-36 years old tend to say nothing should they do as long as they do not affect others to behave the same (40\%).

\section{CONCLUSION}

In Indonesia, program containing LGBT is categorized as a form of information and entertainment that are not in the same breath with Indonesian cultural values system. Norms prevailing in Indonesia still refuses LGBT as a normal thing. Indonesian Broadcasting Commission (KPI) insisted on retaining their decision to block LGBT from public media. But the appearance of sissy characters is not regulated in the Code of Conduct of Broadcasters and Standard od Broadcasting Program (P3SPS). Regarding the norm, there are quite a lot of positive law that do not accommodate the position of LGBT. Law Marriage Law 1 of 1974 does not recognize the term "mating type". Later, Law No. 23 Year 2006 concerning Population Administration does not recognize LGBT. Law No. 4 of 2008 on Pornography includes the term "deviant intercourse" as one element of pornography. In the pornography laws also included prohibited is "intercourse chatter" as "... oral sex, anal sex, lesbian and homosexual". In addition, the Government Regulation No. 54 of 2007 concerning the adoption, explicitly stipulates that adoptive parents cannot be a homosexual couple. Not only that, the Minister of Social Affairs Regulation of 2012 stipulated that the so-called social welfare issues, including those due to their sexual behaviour becomes obstructed in social life, such as; transvestites, gay men and lesbian women.

Based on the above, it appears that LGBT still be the pros and cons. The religious life that is still strong in Indonesia also affect permissiveness. Evidenced by the results of quantitative and qualitative research that both those aged 37 to 66 years and 15 to 36 years, quiet equal to refuse LGBT. The level of permissiveness is higher in younger age groups, especially on the answer about what to do the LGBT persons in his life, they answer as far as not trying to persuade or influence people there is nothing to do.

Therefore both qualitative and quantitative research found that there are no significant differences in opinion and attitude toward LGBT between the age of 15 to 36 years and the age of 37 to 66 years. They mostly said that the LGBT persons are abnormal, and considered them as people who are sick and should be treated by the experts to be back normal. Most of the respondents think that the role of LGBT in TV station should be reduced, because TV stations are considered to be the vehicle to spread the LGBT way of life as a normal life.

\section{References}

1. Wike, R., \& Horowitz, J.M. The Global Divide on Homosexuality: Greater Acceptance in More Secular and Affluent Countries. New York: Pew Research Centre. (2014)

2. P, R. A. Menelisik Perjalanan LGBT di Indonesia. Retrieved March 2, 2016, from Republika Online: $\quad$ http://www.republika.co.id/berita/jurnalisme-warga/wacana/16/01/28/o1n41d336menelisik-perjalanan-lgbt-di-indonesia (2016)

3. Susanto. Civic Intelligence dan Propaganda LGBT. Retrieved March 14, 2016, from Detik.com: http://news.detik.com/kolom/3164153/ltigtcivic-intelligenceltigt-dan-propagandalgbt (2016)

4. Yongliang F, PhD., Lou, C., Gao, E., Tu, X, Cheng, Y, Emerson, M. R., Zabine, L . J. Adolesc. Health, (2011)

5. Riduwan. Metode dan Teknik Menyusun Tesis. Bandung: Alfabeta. (2006) 